\title{
PROSES EVALUASI HASIL BELAJAR DALAM IMPLEMENTASI KURIKULUM 2013 DI MTs AI-JAWAMI
}

\author{
Haidir Ali \\ Pascasarjana Universitas Islam Negeri Sunan Gunung Djati, \\ J1. Cimincrang (Soekarno-Hatta) Kel. Cimincrang Kec. Gedebage Kota Bandung \\ 40294
}

Email: haidirali2004@gmail.com

\begin{abstract}
The process of evaluating learning outcomes in the 2013 curriculum implementation is more comprehensive than KTSP or previous curricula. This evaluation is called authentic assessment. But in practice, teachers still find it difficult to implement evaluation procedures in this new curriculum. Especially in madrasas where the implementation of the 2013 curriculum is still not getting serious attention. This is the background of this study. The approach used in this study is a qualitative approach with descriptive methods. This research was conducted at MTs Al-Jawami Cileunyi Bandung which has been using this curriculum since 2015. The data collection technique is by interview and documentation. From the results of the interviews, the researchers concluded that the learning process using the 2013 curriculum in Al-Jawami MTs as a whole had run quite well, the students could have been made to be more active and creative, and the teachers were more creative in creating fun learning that was studentcentered. But unfortunately good learning has not been accompanied by evaluation as it should evaluate learning outcomes in the 2013 curriculum implementation. Many factors have led to this, among others, perceived lack of training, inadequate facilities and infrastructure, and lack of understanding of computer technology for some Al MTs teachers -Jawami.Abstract should be written in Indonesian and English using Book Antiqua font, size $10 \mathrm{pt}$, and italic, single spasing. Abstract is not a merger of several paragraphs, but it is a full and complete summary that describe content of the paper It should contain background, objective, methods, results, and conclusion from the research. It is should not contain any references nor display mathematical equations. It consists of one paragraph and should be no more than 150 words in English.
\end{abstract}

Keywords: Evaluation, Learning Outcomes, 2013 Curriculum

\begin{abstract}
Abstrak : Proses evaluasi hasil belajar dalam implementasi kurikulum 2013 lebih menyeluruh dibandingkan dengan KTSP atau kurikulum-kurikulum sebelumnya. Evaluasi ini disebut authentic assessment atau penilaian otentik. Namun pada praktiknya, guru-guru masih merasa kesulitan melaksanakan prosedur evaluasi pada kurikulum baru ini. Terutama di madrasah yang implementasi kurikulum 2013 ini masih kurang mendapat perhatian yang serius. Hal tersebut yang menjadi latar belakang penelitian ini. Pendekatan yang digunakan pada penelitian ini adalah pendekatan kualitatif dengan metode deskriptif. Penelitian ini dilakukan di MTs Al-Jawami Cileunyi Bandung yang telah menggunakan kurikulum ini sejak tahun 2015. Adapun teknik pengumpulan datanya adalah dengan wawancara dan dokumentasi. Dari hasil wawancara, peneliti menyimpulkan bahwa proses pembelajaran dengan menggunakan kurikulum 2013 di MTs Al-Jawami secara keseluruhan telah berjalan dengan cukup baik, para siswa telah dapat dibuat untuk lebih aktif dan kreatif, dan para guru lebih kreatif dalam menciptakan pembelajaran menyenangkan yang berpusat pada siswa. Namun sayangnya pembelajaran yang baik itu belum diiringi dengan evaluasi sebagai mana mestinya evaluasi hasil belajar dalam implementasi kurikulum 2013. Banyak faktor yang menyebabkan hal ini diantaranya dirasa kurangnya pelatihan, sarana dan prasarana yang belum memadai, serta kurangnya pemahanan tentang teknologi komputer bagi beberapa guru MTs Al-Jawami.
\end{abstract}

Kata Kunci: Evaluasi, Hasil Belajar, Kurikulum 2013 


\section{PENDAHULUAN}

Persoalan pendidikan muncul bersamaan dengan adanya manusia itu sendiri di atas dunia (hidup) oleh karena manusia itu merupakan "homo educandum" artinya manusia itu pada hakikatnya merupakan makhluk yang disamping dapat dan harus dididik, juga dapat dan harus mendidik (Soelaiman Joesoef, 1999: 65-66). Oleh karena itu sepanjang hidupnya manusia akan senantiasa terlibat secara langsung dalam pendidikan. Dewasa ini, ilmu pengetahuan dan teknologi secara global berkembang dengan sangat pesat. Indonesia sebagai bagian dari bangsa-bangsa di dunia harus mampu mengimbangi perkembangan tersebut. Jika tidak, maka Indonesia akan tertinggal bahkan terkucilkan di hadapan bangsa-bangsa lain. Maka peningkatan sumber daya manusia menjadi prioritas utama, dan salah satu faktor terpenting yang dapat mempengaruhinya ialah pendidikan.

Kualitas pendidikan di Indonesia saat ini masih memprihatinkan. Data menunjukkan bahwa Human Development Index (Indeks Pengembangan Manusia, salah satu komposisinya adalah pencapaian pendidikan) negara kita pada tahun 2018 berada pada ranking 113 dari sekitar 180 negara di dunia (sumber: hrd.undp.org). Oleh sebab itu segala perbaikan di semua aspek pembangunan perlu ditingkatkan, khususnya di dunia pendidikan sebagai salah satu upaya untuk mencetak sumber daya manusia yang unggul.

Untuk mengantisipasi tuntutan di atas, pemerintah terus berupaya untuk merespon lajunya perkembangan ilmu dan teknologi global. Peningkatan mutu pendidikan terus diupayakan, salah satunya adalah dengan melakukan pembenahan dan penyempurnaan terhadap aspek substantif yang mendukung kinerja pendidikan, yaitu kurikulum sekolah. Kurikulum memegang kedudukan kunci dalam pendidikan, sebab berkaitan dengan penentuan arah, isi dan proses pendidikan yang pada akhirnya menentukan macam dan kualifkasi lulusan suatu lembaga pendidikan. Kurikulum menyangkut rencana dan pelaksanaan pendidikan baik dalam lingkup kelas, sekolah, daerah, wilayah, maupun nasional.

Kurikulum yang digunakan saat ini adalah kurikulum 2013. Orientasi kurikulum 2013 adalah terjadinya peningkatan dan keseimbangan antara kompetensi sikap (attitude), keterampilan (skill) dan pengetahuan (knowledge). Sejalan dengan amanat UU No. 20 Tahun 2003 sebagaimana tersurat dalam penjelasan pasal 35: kompetensi lulusan merupakan kualifikasi kemampuan lulusan yang mencakup sikap, pengetahuan, dan keterampilan sesuai dengan standar nasional yang telah disepakati. Secara konseptual draft kurikulum 2013 dicita-citakan untuk mampu melahirkan generasi masa depan yang cerdas komprehensif yakni tidak hanya cerdas intelektualnya, tetapi juga cerdas emosi, sosial dan spiritualnya.

Salah satu perubahan penting pada kurikulum baru ini adalah proses evaluasi. Evaluasi merupakan proses penting dalam pendidikan. Evaluasi akan memberikan gambaran secara global tentang ketercapaian tujuan-tujuan pendidikan. Dengan adanya evaluasi, proses pendidikan akan terus dapat terbarukan dan menjadi semakin baik. Karena pendidikan dituntut untuk memenuhi kebutuhan masyarakat sesuai dengan 
keadaan masyarakat pada masanya, maka evaluasi menjadi sangat penting untuk terus dilakukan. Dari hasil evaluasi akan didapatkan keterangan-keterangan yang menunjukkan tentang kelemahan dan kelebihan dari serangkaian proses pendidikan, untuk kemudian dilakukan perbaikan bagi kelemahannya dan peningkatan kualitas bagi kelebihannya.

Menjadi hal yang menarik untuk diteliti tentang bagaimana pelaksanaan evaluasi pada kurikulum baru ini di madrasah, karena berbeda dengan sekolah, madrasah memiliki ciri khas tersendiri yang berorientasi pada internalisasi nilai-nilai ajaran agama Islam. Oleh karena itu, peneliti merasa tertarik untuk meneliti tentang bagaimana proses evaluasi di madrasah yang menggunakan kulikulum 2013.

Berdasarkan latar belakang di atas, agar peneliti lebih terarah maka yang menjadi masalah dalam penelitian ini adalah: Bagaimana proses evaluasi hasil belajar dalam implementasi kurikulum 2013 di MTs Al-Jawami Desa Cileunyi Wetan Kecamatan Cileunyi Kabupaten Bandung? Adapun tujuan yang ingin dicapai dari penelitian ini adalah untuk mengetahui: Proses evaluasi hasil belajar dalam implementasi kurikulum 2013 di MTs Al-Jawami Desa Cileunyi Wetan Kecamatan Cileunyi Kabupaten Bandung.

\section{METODOLOGI PENELITIAN}

\section{Pendekatan dan Metode Penelitian}

Penelitian ini menggunakan metode deskriptif dengan pendekatan kualitatif. Metode deskriptif adalah suatu metode dalam meneliti status sekelompok manusia, suatu objek, suatu set kondisi, suatu sistem pemikiran, ataupun suatu kelas peristiwa pada masa sekarang (Moh. Nazir, 2011: 54). Pendekatan kualitatif dipilih, karena mengingat permasalahan yang muncul bersifat kompleks, dinamis, dan penuh makna sehingga data tidak mungkin dapat dijaring dengan pendekatan kuantitatif.

\section{Waktu dan Tempat Penelitian}

Penelitian dilaksanakan selama bulan Juni 2018. Adapun tempat penelitiannya ialah di MTs Al-Jawami Desa Cileunyi Wetan Kecamatan Cileunyi Kabupeten Bandung.

\section{Sumber dan Teknik Pengumpulan Data}

Sumber data utama dalam penelitian kualitatif adalah kata-kata dan tindakan, selebihnya adalah tambahan seperti dokumen dan lainnya (S. Margono, 2003: 158). Untuk itu teknik pengumpulan data yang digunakan adalah wawancara dan dokumentasi.

\section{a. Wawancara}

Wawancara adalah bentuk komunikasi langsung antara peneliti dan responden. Komunikasi berlangsung dalam bentuk tanya jawab dalam hubungan tatap muka, sehingga gerak dan mimik responden merupakan pola media yang melengkapi kata-kata secara verbal (W. Gulo, 2010: 119).

b. Dokumentasi

Dokumen adalah catatan tertulis tentang berbagai kegiatan atau peristiwa pada waktu yang lalu (W. Gulo, 2010: 123). Dalam penelitian kualitatif, teknik ini 
merupakan alat pengumpul data yang utama karena pembuktian hipotesisnya yang diajukan secara logis dan rasional.

\section{HASIL PENELITIAN DAN PEMBAHASAN}

\section{Hasil Penelitian}

Pada mini riset ini peneliti melakukan wawancara. Peneliti mewawancarai tiga orang, yakni kepala sekolah, wakasek kurikulum, dan wakasek kesiswaan yang kebetulan ketiga narasumber tersebut juga sebagai guru mata pelajaran. Adapun hasil wawancara ialah sebagai berikut:

a. Hasil Wawancara dengan Kepala Sekolah

Biodata Singkat:

Nama Lengkap : : Supriyadi, S.Ag.

TTL

: Cirebon, 18 Juli 1976

Alamat

: Perum GPAA Sindang Palun Kec. Cimanggung

Kab. Sumedang

Jabatan

: Kepala Madrasah / Guru Fiqih

Pendidikan Terakhir

: S1 (IAIN Sunan Gunung Djati Bandung)

Hasil Wawancara:

\begin{tabular}{|l|l|}
\hline \multicolumn{1}{|c|}{ Pertanyaan } & \multicolumn{1}{|c|}{ Jawaban } \\
\hline $\begin{array}{l}\text { Bagaimana tanggapan anda terhadap } \\
\text { kurikulum 2013? }\end{array}$ & $\begin{array}{l}\text { Kurikulum 2013 ini baik, siswa } \\
\text { menjadi lebih aktif. Tetapi kurangnya } \\
\text { Diklat berdampak pada guru yang } \\
\text { masih banyak merasa bingung dalam } \\
\text { implementasinya, terutama masalah } \\
\text { penilaian. Terlebih lagi guru dituntut } \\
\text { untuk mengusai ICT, hal ini menjadi } \\
\text { beban berat bagi guru-guru "senior". }\end{array}$ \\
\hline $\begin{array}{l}\text { Apa perbedaan mendasar KTSP } \\
\text { dengan Kurikulum 2013 di sekolah } \\
\text { ini? }\end{array}$ & $\begin{array}{l}\text { KTSP itu berbasis budaya sekolah } \\
\text { yang ada, sedangkan pada kurikulum } \\
\text { 2013 lebih ditekankan pada } \\
\text { pengamalan akhlak dan budi pekerti. }\end{array}$ \\
\hline $\begin{array}{l}\text { Bagaimana pelaksanaan pembelajaran } \\
\text { dengan menggunakan kurikulum 2013 } \\
\text { di sekolah ini? }\end{array}$ & $\begin{array}{l}\text { Berjalan dengan baik, siswa menjadi } \\
\text { lebih aktif, pembelajaran menjadi } \\
\text { lebih hidup. Tetapi tergantung pada } \\
\text { cara mengajar gurunya itu sendiri. }\end{array}$ \\
\hline $\begin{array}{l}\text { Bagaimana evaluasi hasil belajar dari } \\
\text { pembelajaran dengan menggunakan } \\
\text { kurikulum 2013 di sekolah ini? }\end{array}$ & $\begin{array}{l}\text { Evaluasi telah menggunakan format } \\
\text { yang tersedia, berbasis komputer, } \\
\text { tetapi guru-guru yang sudah tua masih } \\
\text { kebingungan menggunakannya } \\
\text { sehingga belum berjalan dengan } \\
\text { maksimal. }\end{array}$ \\
\hline
\end{tabular}




\begin{tabular}{|l|lll|}
\hline $\begin{array}{l}\text { Jika anda harus memilih, anda akan } \\
\text { memilih KTSP atau Kurikulum 2013? }\end{array}$ & $\begin{array}{l}\text { Lebih ke kurikulum 2013, tetapi } \\
\text { memang banyak yang harus } \\
\text { dievaluasi. }\end{array}$ \\
\hline
\end{tabular}

Hasil Wawancara dengan Wakasek Kurikulum

Biodata Singkat:

Nama Lengkap : : Ujang Syamsul, S.Pd.I.

TTL

: Sukabumi, 01 Februari 1983

Alamat

: Kom. Pon-Pes Al-Jawami RT 03/RW 21 Ds Cileunyi

Wetan Kec. Cileunyi Kab. Bandung

Jabatan : Wakasek Kurikulum / Guru B. Arab

Pendidikan Terakhir : S1 (IAIN Sunan Gunung Djati Bandung)

Hasil Wawancara:

\begin{tabular}{|c|c|}
\hline Pertanyaan & Jawaban \\
\hline $\begin{array}{l}\text { Sejak kapan mulai implementasi } \\
\text { Kurikulum 2013? }\end{array}$ & $\begin{array}{l}\text { Sejak pertengahan semester tahun } \\
\text { ajaran } 2014 / 2015 \text { ini. Dua bulan } \\
\text { pertama masih KTSP. }\end{array}$ \\
\hline $\begin{array}{l}\text { Bagaimana kesiapan para guru } \\
\text { menerapkan kurikulum baru ini? }\end{array}$ & $\begin{array}{l}\text { Para guru belum sepenuhnya siap, } \\
\text { karena kurangnya pelatihan. }\end{array}$ \\
\hline $\begin{array}{l}\text { Pernah ada pelatihan? Kapan? } \\
\text { Dimana? }\end{array}$ & $\begin{array}{l}\text { Untuk pelatihan yang diikuti oleh } \\
\text { semua guru tentang pembelajaran, } \\
\text { pernah ada pelatihan di MTsN } \\
\text { Cikancung pada bulan Oktober 2014, } \\
\text { itupun hanya satu hari. Untuk pelatihan } \\
\text { tentang aplikasi penilaian kurtilas yang } \\
\text { diikuti hanya oleh kepala madrasah } \\
\text { dan wakasek kurikulum itu pada } \\
\text { tanggal } 19 \text { November } 2014 \text { di tempat } \\
\text { yang sama dan juga hanya satu hari. }\end{array}$ \\
\hline $\begin{array}{l}\text { Apa perbedaan mendasar } \\
\text { dengan Kurikulum } 2013 \text { di sekolah } \\
\text { ini? }\end{array}$ & $\begin{array}{l}\text { Penilaian yang lebih menyeluruh, } \\
\text { penambahan jam pelajaran pada } \\
\text { beberapa mata pelajaran, pada } \\
\text { pembelajaran siswa dituntut lebih } \\
\text { aktif, tata kerja guru menjadi } \\
\text { kolaboratif serta tuntutan penguasaan } \\
\text { ICT. }\end{array}$ \\
\hline $\begin{array}{l}\text { Bagaimana tentang ketersediaan } \\
\text { sarana, media dan sumber belajar } \\
\text { penunjang kurikulum } 2013 \text { ? }\end{array}$ & $\begin{array}{l}\text { Sekolah kami baru memiliki } 1 \text { buah } \\
\text { proyektor, maka digunakan secara } \\
\text { bergantian dan belum maksimal. } \\
\text { Untuk buku-buku paket juga tidak } \\
\text { lengkap, sampai saat ini baru ada buku } \\
\text { Fiqih, SKI, Aqidah Akhlak, Qur'an }\end{array}$ \\
\hline
\end{tabular}




\begin{tabular}{|c|c|}
\hline & $\begin{array}{l}\text { Hadits, dan Bahasa Arab saja, untuk } \\
\text { mata pelajaran lain belum ada dan } \\
\text { itupun telat datangnya. Maka dalam } \\
\text { mengajar, guru print sendiri soft file } \\
\text { yang didapat saat pelatihan dan } \\
\text { memerintahkan siswa untuk fotocopy } \\
\text { sendiri. }\end{array}$ \\
\hline $\begin{array}{l}\text { Kendala dalam } \quad \text { implementasi } \\
\text { kurikulum } 2013 \text { di sekolah ini? }\end{array}$ & $\begin{array}{l}\text { Guru belum sepenuhnya menguasai } \\
\text { karena tadi kurangnya sosialisasi dan } \\
\text { pelatihan. Memang } 100 \% \text { sekolah } \\
\text { telah melaksanakan kurtilas ini, tetapi } \\
\text { tingkat penguasaan guru terhadap } \\
\text { kurikulum ini mungkin hanya sekitar } \\
75 \% \text {. }\end{array}$ \\
\hline $\begin{array}{l}\text { Bagaimana evaluasi hasil belajar dari } \\
\text { pembelajaran dengan menggunakan } \\
\text { kurikulum } 2013 \text { di sekolah ini? }\end{array}$ & $\begin{array}{l}\text { Guru-guru yang biasa memberi nilai } \\
\text { hanya berdasarkan hasil ujian, } \\
\text { sekarang mereka mulai menilai aspek } \\
\text { lain dengan lebih menyeluruh, karena } \\
\text { tuntutan kurtilas ini. Tetapi memang } \\
\text { diakui evaluasinya masih belum } \\
\text { sepenuhnya berjalan dengan baik }\end{array}$ \\
\hline $\begin{array}{l}\text { Secara keseluruhan, bagaimana } \\
\text { tanggapan anda terhadap kurikulum } \\
\text { 2013? }\end{array}$ & $\begin{array}{l}\text { Sangat setuju, karena guru akan lebih } \\
\text { dituntut profesionalitasnya dalam } \\
\text { mengajar dan benar-benar menilai } \\
\text { secara menyeluruh, bukan menilai dari } \\
\text { hasil ujian saja, tetapi semua sikap } \\
\text { siswa juga dinilai. Umat Islam harus } \\
\text { mendukung kurikulum ini, karena } \\
\text { pembentukan akhlak sangat } \\
\text { diperhatikan di dalam kurtilas ini. }\end{array}$ \\
\hline
\end{tabular}

b. Hasil Wawancara dengan Wakasek Kesiswaan

Biodata Singkat:

Nama Lengkap $\quad$ : Bani M. Tsabit, M.Si.

TTL

: Bandung, 17 Januari 1978

Alamat

: Kom. Pon-Pes Al-Jawami RT 03/RW 21 Ds Cileunyi

Wetan Kec. Cileunyi Kab. Bandung

Jabatan : : Wakasek Kesiswaan / Guru Qurdis

Pendidikan Terakhir : S2 (IAIN Kalijaga Yogyakarta)

Hasil Wawancara: 


\begin{tabular}{|l|l|}
\hline \multicolumn{1}{|c|}{ Pertanyaan } & \multicolumn{1}{|c|}{ Jawaban } \\
\hline $\begin{array}{l}\text { Bagaimana tanggapan anda terhadap } \\
\text { kurikulum 2013? }\end{array}$ & $\begin{array}{l}\text { Bagus, karena siswa menjadi lebih } \\
\text { aktif dan guru menjadi lebih kreatif. }\end{array}$ \\
\hline $\begin{array}{l}\text { Apa perbedaan mendasar KTSP } \\
\text { dengan Kurikulum 2013 di sekolah } \\
\text { ini? }\end{array}$ & $\begin{array}{l}\text { Penilaian lebih mendalam, jam } \\
\text { pelajaran dalam } \\
\text { pembelajaran guru hanya tinggal } \\
\text { melaksanakan apa yang ada di buku. }\end{array}$ \\
\hline $\begin{array}{l}\text { Bagaimana pelaksanaan pembelajaran } \\
\text { dengan menggunakan kurikulum 2013 } \\
\text { di sekolah ini? }\end{array}$ & $\begin{array}{l}\text { Belum maksimal, karena fasilitas, } \\
\text { juknis, buku-buku semuanya telat dan } \\
\text { belum merata. Dapat dikatakan dalam } \\
\text { pelaksanaannya baru setengah jalan. }\end{array}$ \\
\hline $\begin{array}{l}\text { Bagaimana evaluasi hasil belajar dari } \\
\text { pembelajaran dengan menggunakan } \\
\text { kurikulum 2013 di sekolah ini? }\end{array}$ & $\begin{array}{l}\text { Sudah berjalan tetapi belum maksimal. } \\
\text { Guru-guru yang sudah senior merasa } \\
\text { kesulitan dengan format penilaian baru } \\
\text { di dalam kurikulum baru ini. }\end{array}$ \\
\hline $\begin{array}{l}\text { Jika anda harus memilih, anda akan } \\
\text { memilih KTSP atau Kurikulum 2013? }\end{array}$ & $\begin{array}{l}\text { Lebih cenderung ke kurikulum 2013, } \\
\text { hanya saja masih dirumitkan masalah } \\
\text { penilaian. }\end{array}$ \\
\hline
\end{tabular}

\section{Analisis Data Penelitian}

Dari penelitian yang telah peneliti lakukan di MTs Al-Jawami Kecamatan Cileunyi Kabupaten Bandung, maka peneliti mendapatkan bahwa guru-guru MTs AlJawami belum sepenuhnya menguasai kurilulum 2013 ini, karena terlambat dan kurangnya pelatihan, tetapi kurikulum ini tetap digunakan sejak tahun ajaran 2014-2015 ini. Namun walau pun dirasa kurang, pelatihan-pelatihan yang diagendakan oleh pemerintah tentunya bukan hal yang sia-sia, karena pada dasarnya di kurikulum ini guru hanya menjalankan apa yang ada di buku guru, dan soft file buku-buku kurtilas telah dibagikan pada pelatihan tersebut. Maka untuk proses pembelajaran tidak terlalu menjadi permasalahan, dan guru-guru telah mengarah pada pembelajaran kurtilas yang diharapkan walaupun masih harus terus ditingkatkan.

Berbeda dengan KTSP, evaluasi kurikulum 2013 jauh lebih rumit. Hal inilah yang menjadi permasalahan yang cukup serius bagi para guru MTs Al-Jawami, terutama guru "senior" karena harus menggunakan komputerisasi. Untuk penilaian kurtilas, pelatihan yang hanya satu hari sangatlah kurang. Kepala madrasah dan Wakasek kurikulum yang mengikuti pelatihan saja masih belum sepenuhnya menguasai, ditambah lagi mereka berdua yang harus menyampaikan cara kerja aplikasi penilaian kurtilas ini kepada semua guru, hal ini sungguh tidak masuk akal. Akhirnya untuk evaluasi hasil belajar di MTs Al-Jawami berjalan dengan apa adanya, secara kurang maksimal. 


\section{Haidir Ali}

\section{SIMPULAN}

Implementasi kurikulum 2013 masih banyak menemui permasalahan, mulai dari sosialisasi kurikulum dan pelatihan yang dirasa kurang, keterlambatan buku-buku paket, setra ketersediaan sarana prasarana yang belum memadai, terlebih lagi di madrasahmadrasah swasta. Namun di luar berbagai permasalahan yang terjadi, para guru MTs AlJawami mendukung kurikulum baru ini untuk diterapkan. Kurikulum 2013 dinilai baik, jika dilaksanakan dengan maksimal.

Proses pembelajaran dengan menggunakan kurikulum 2013 di MTs Al-Jawami secara keseluruhan telah berjalan dengan cukup baik, para siswa telah dapat dibuat untuk lebih aktif dan kreatif, dan para guru harus lebih kreatif dalam menciptakan pembelajaran menyenangkan yang berpusat pada siswa. Namun sayangnya pembelajaran yang baik itu belum diiringi dengan evaluasi sebagai mana mestinya evaluasi hasil belajar dalam implementasi kurikulum 2013, sehingga cita-cita kurikulum 2013 dengan penilaian Authentic masih belum dapat sepenuhnya dilaksanakan di MTs Al-Jawami.

\section{DAFTAR PUSTAKA}

Daryanto. 2008. Evaluasi Pendidikan. Jakarta: PT Rineka Cipta.

Departemen Pendidikan Nasional. 2008. Kamus Besar Bahasa Indonesia, Jakarta: Gramedia Pustaka Utama.

Jusuf Sjarif Badudu dan Sutan M. Zain. 1996. Kamus Umum Bahasa Indonesia. Jakarta: Pustaka Sinar Harapan.

Lukmanul Hakim Abdullah. 2013. Sistem Penilaian dalam Kurikulum 2013: Kajian Dokumen Terhadap Kurikulum 2013 [Paper]

Moh. Nazir. 2011. Metode Penelitan. Bogor: Penerbit Ghalia Indonesia.

S. Margono. 2003. Metodologi Penelitian. Jakarta: Rineka Cipta.

Soelaiman Joesoef. 1999. Konsep Dasar Pendidikan Luar Sekolah. Jakarta: PT Bumi Aksara.

Soewarno Handayaningrat. 1988. Pengantar Studi Ilmu Administrasi dan Manajemen. Jakarta: PT Toko Gunung Agung.

W. Gulo. 2010. Metodologi Penelitian. Jakarta: PT Grasindo. 